\title{
Healing in the Sámi North
}

\author{
Randall Sexton • Ellen Anne Buljo Stabbursvik
}

Published online: 16 September 2010

(C) The Author(s) 2010. This article is published with open access at Springerlink.com

\begin{abstract}
There is a special emphasis today on integrating traditional healing within health services. However, most areas in which there is a system of traditional healing have undergone colonization and a number of pressures suppressing tradition for hundreds of years. The question arises as to how one can understand today's tradition in light of earlier traditions. This article is based on material collected in Sámi areas of Finnmark and Nord-Troms Norway; it compares local healing traditions with what is known of earlier shamanic traditions in the area. The study is based on 27 interviews among healers and their patients. The findings suggest that although local healing traditions among the Sámi in northern Norway have undergone major transformations during the last several hundred years, they may be considered an extension of a longstanding tradition with deep roots in the region. Of special interest are also the new forms tradition may take in today's changing global society.
\end{abstract}

Keywords Healing · Sámi $\cdot$ Traditional $\cdot$ Shamanism $\cdot$ Integration

\section{Introduction: The Meeting of Three Tribes}

This article focuses primarily on the healing traditions of Finnmark and Nord-Troms, the two most northerly counties in Norway, and a crossroad of three cultures-or, as said locally, the "meeting point of three tribes." These are the Sámi, an indigenous people residing in the area for at least 9,000 years (Haetta 1993; Ingman and Gyllensten 2007), the Kven, Finnish descendents who first came to farm in the area

\footnotetext{
R. Sexton $(\bowtie)$

Psychiatric Research Group, Institute of Clinical Medicine, Faculty of Health Sciences, University of Troms $\emptyset$, P.O. Box 6124, 9291 Troms $\emptyset$, Norway

e-mail: randallno@yahoo.com

E. A. B. Stabbursvik

Samisk Nasjonalt Kompetansesenter - Psykisk Helsevern, Helsetunveien 2, 9700 Lakselv, Norway
} 
about 300 years ago, and Norwegians who have had a presence in the area probably since the thirteenth century, originally arriving in connection with the fishing trade and, at that time, primarily holding trading posts along the coast (NOU 1994). In addition to being a crossroad of cultures and their integral worldviews, this region is now at a crossroads between tradition and the modern era, where the traditional lifestyles of fishing, farming and reindeer herding are giving way to modern ways of life in an era colored by the recent oil wealth and socialized policies of Norway.

The Sámi are historically several different yet related cultures spanning large areas of northern Norway, Sweden, Finland, and Northwest Russia, all with their own languages and history-the northern (coastal and inland), southern, Lule, Skolte, Pite and Inari cultures and language variations being some examples. Although this article primarily focuses on the northern coastal and inland Sámi healing traditions of this region, these are to some extent representative of practices throughout the multicultural (Sámi, Norwegian and Kven) regions of Finnmark and Nord-Troms as cultures have blended and merged throughout centuries. Although the communities in this area are geographically close, they are in many ways diverse, as the livelihoods and extent of assimilation and intercultural marriage have varied. Inland communities generally have a more preserved and apparent Sámi culture, while coastal communities have been more clearly marked by the combined effects of assimilation policies, close proximity to Norwegian communities and earlier laws that disfavored those with Sámi ancestry. One such law made it illegal for those with Sámi names to own land, which was particularly devastating for coastal Sámi who lived on small-scale fishing and farming. The law resulted in many choosing new names and concealing their own backgrounds in various ways.

Today, there is increased and international emphasis on rethinking health services in light of local (sometimes indigenous) practices, worldviews and understandings (World Health Organization 2002), a call especially emphasized within mental health services (Kirmayer et al. 2000). But though there is also an emphasis on providing culturally relevant health services to the Sámi people in Norway, there is often still little awareness of local traditions among health professionals in the area. While some therapists believe that a more traditional shamanism, little changed from the past, is still practiced, many seem hardly aware of any particular healing traditions presently in use. In a study carried out in 2005 at the university hospital catering to this region, therapists were found to show only slight awareness of their client's use of traditional helpers. While over a third of the Sámi clients had used helpers in relation to their current problem, less than half reported that this was given any consideration during the hospital stay (Sørlie and Nergård 2005). This reflects a longstanding tendency within the health services to disregard local healing traditions, as well as a tendency among many clients to avoid bringing up the subject. At the same time, the fact that some consideration was given may reflect an increasing openness to local helping traditions, probably due to both a growing focus on culture within the health services and on healing traditions within the media and the culture at large. Another more recent study has shown that patients have a clear desire for a greater representation of local healing tradition within the health services (Sexton and Sørlie 2009).

This article seeks to provide some background on these healing practices of this region today, focusing specifically on the worldviews that seem to underlie the 
tradition, and viewing these in light of what is known of Sámi healing traditions of the past. It also looks at the recent efforts to revitalize earlier shamanic traditions, a movement happening both in rural communities and in some urban environments of larger cities throughout the country. These healing practices, whether they be those of the traditional helpers in northern rural towns, or of modern-day healers or shamans in a variety of environments, are of special interest as the Sámi are unique as an indigenous people of Northern Europe today-not only with respect to their distinct origin, cultural heritage and longstanding existence in this arctic region, but also with respect to the important presence they have as an indigenous community in the midst of an increasingly modern and globalized world.

\section{Help in Times of Need: An Opening Story}

The following is a short opening account of an elderly woman and healer who on several occasions had experienced being protected by some form of helper. Like many of the narratives, it portrays some of the worldviews central to local healing tradition, views that may also be linked to traditions and symbolism of the past. The story is told of an experience she had while walking in a snow-covered area.

I was walking along the wall of a house that had been taken down and moved after the landslide in the area, and there was snow on the ground. First I followed along some footprints in the snow, and then I was going to pass by a boulder above the house. As I started walking towards the boulder, I raised my foot to take a step and suddenly felt two strong male hands on my shoulders that pulled me back. Oh, how powerful those hands were! I turned around to see who had been following me, and nobody was there. Then I looked in front of me again, and saw that I was just about to step into a well. There were just some boards laying over that well and some snow above them, and when I pushed them aside I saw how deep it was, and I thought to myself, "Had I had fallen in that well, no one would have found me, no one would have known where I had disappeared." Afterwards, the reaction came. I could hardly walk up the hill to the road. I was so weak in my knees, at the thought that I could have ended my days in that well. The night before I dreamt that I was out traveling, going to take a ferry from Lyngseidet. I was in a hurry, and there was a little ferry at the dock. I was going to go on board. Just as I lifted my foot, the ferry took off from me. They waved and smiled to me from on board and were glad, smiled when I didn't come along. It was exactly as had happened later that day, when I lifted my foot and was going to take a step. Had I come on board that ferry, I would have drowned. It was only a warning for me.

The elderly woman who recounted this story was herself strongly rooted in the Laestadian church of the area, a Christian movement initiated during the nineteenth century that has had a strong appeal to many Sámi people. She would often refer to the helpers, such as the one in her near-accident, as angels. She had lived a rich, though difficult life, about which she had many vivid stories to share, and was sought by many for help in the coastal area where she lived. After meeting her, the first author later met 
a person who himself was struggling with psychological aftereffects of a neardrowning accident. He told how he had brought his wife to this elderly healer for help with a shoulder problem. Although he himself had not sought her for his own problems, he told how the stories she shared from her own life during their visit had made a very deep impression on him, "I did not tell her of my problems, but it was fantastic to hear her stories," he explained—emphasizing that the stories helped him believe in a force outside himself: in "the Universe," as he put it.

\section{Conceptual and Methodological Framework of the Study}

Initially, the purpose of the project was to look at patient and healer perspectives toward an integration of traditional healing within health services, the primary subject of the Ph.D. project of the first author. As the project progressed, we collected many narratives portraying aspects of traditional healing today and began to consider an article primarily on traditional healing, also clearly central to the question of integration. However, it became clear very early that traditional healing is a sensitive issue for many. Although most healers we spoke with had chosen to be open, some had a harder time talking about tradition, explaining that it was an inner experiential knowledge that really could not be shared: that not speaking of it was itself a part of the tradition. There has clearly been a silence around helping and healing practices that has today eased among some, and still exists among others, especially those living in inland regions. Considering this silence, one can question whether Sámi healing tradition ought to be made a subject of research at all and, if so, how.

These considerations have guided the framework of this study. The goal is therefore not an attempt at a revealing analysis of the details of local tradition, but a highlight of the worldviews within which it seems to be set. For this reason, we also chose to primarily use interviews, rather than observation of healing work that could be experienced as invasive for some healers and their clients.

We see the ethnographic and qualitative approach used here in the light of a reflexive research tradition (Gergen 1999) that recognizes the integral role that context and the researcher's own background play in forming the reality emerging from the study. This reality is therefore considered only one reflection of local healing practices.

\section{Participants and Interviews}

The study was approved by the regional ethical committee and is based on interviews with a total of 27 people from the region. Although all had a Sámi background, most Sámi in Norway consider themselves both Norwegian and Sámi (Sørlie and Nergård 2005), and some in this study also had a mixed family heritage of Sámi and Norwegian or of Sámi, Norwegian and Kven.

Eight of the interviews were with healers, and the remainder with clients of healers, or with people who were familiar with local tradition, and were carried out between 2003 and 2010, with most occurring in 2006 and 2007. A number of the clients of healers were recruited through their participation in a study on the 
interfaces of traditional and Western mental health services in Nord-Troms and Finnmark. Nineteen interviews were recorded, and audio notes were taken immediately after the other eight. Nine of the interviews were in Sámi.

Interviews were open in form and mostly carried out in people's homes, with a focus on providing a space for them to share their own personal stories and backgrounds, independent of whether these were initially thought to be related to local healing tradition. Experiences within local healing traditions were entered on when this seemed natural during the course of the conversations. Some of the interviews were followed up with subsequent conversations, in some cases over a period of several years.

In addition to these interviews are some observations from the region noted by both authors. We have quite different backgrounds and have held different roles in this study. Ellen Anne comes from a reindeer-herding family of the area and grew up in the vicinity of the inland town of Kautokeino. She has worked as a psychiatric nurse's aide within the mental health services of the area for over 30 years and, during this time, has had close contact with clients using both traditional healers and the public health services. At times she has accompanied them on their visits to healers, sometimes witnessing seemingly remarkable cures. Her main role in this study was in carrying out the interviews in Sámi in and around Kautokeino. Randall carried out the Norwegian interviews in inland and coastal areas as a part of a Ph.D. project and has worked on framing the themes in the interview material within what is known of both shamanic and earlier Sámi healing traditions. Originally from Alaska, his first experiences in the area were during a general practice residency in Kautokeino in 1993 and, later, while working within psychiatry in the region. These experiences strongly contributed to an interest in Sámi healing traditions and a gradual acquaintance with several Sámi healers. His own background as a Holotropic breathwork practitioner also relates to themes in this article, in that the practice-similar to some traditional healing practices_utilizes music, breath and heightened states of awareness as therapeutic tools.

\section{Analysis}

Analysis was a continual process throughout the project. Notes were taken of observations in the region, after less formal conversations and after interviews that were transcribed and, when in Sámi, translated into Norwegian. These were discussed with colleagues and used to find themes relating to worldviews, ways of helping and ways of knowing.

\section{Background on Shamanic Healing Practices}

Before Christianity came to the area, healing was carried out by the noaidi, or shaman, in the small, mostly nomadic, Sámi groups. According to Hultzkrantz, who has researched in depth the historical sources of Sámi shamanism, there are four important constituents of shamanism: the cosmology of a supernatural world and the contacts with it the shaman as the actor on behalf of a human group the inspiration 
granted him by his helping sprits and the ecstatic experiences of the shaman (Backman and Hultkrantz 1978).

There has been, for many years, an ongoing academic debate as to what shamanism actually is. Part of this debate may spring from what has been pointed out as its "chameleon-like elusiveness," with thought that is more "fluid than doctrinal" (Vitebsky 2001, p. 292). Although the term shaman originally arises from the Tungus language and culture of Siberia, where the soul-flight of the shaman seems to be a defining characteristic, no generally agreed on cross-cultural definition of shamanism exists, and the term is often used in a broader sense across cultures today, sometimes referring to an individual who, through inspiration, gift or learning, has visionary or psychic abilities that are used for the benefit of others. In addition to soul-flight, this may include communication with spirits or spirit incorporation.

The center of attention on shamanism has changed radically through the evolving discourses in Western science and culture. While first considered devil worshipers by conquerors and missionaries, and later as charlatans or psychotics by many of the first anthropologists to encounter them, shamans are today often viewed as specialists who hold privileged positions in their societies (Krippner 2002). Although it is widely acknowledged that shamans in many cultures carried out different forms of spiritual warfare and sorcery, and that the tools and knowledge could be used equally for destructive or constructive ends, it is also clear that a guiding code of ethics has been fundamental to practice in many cultures (Dow 1986). The discussions on shamanism today seem to hinge primarily on two differing perspectives that are particularly actualized in today's globalized era. On the one hand, there is an understanding of shamanism as a cultural expression situated in a particular time and place, with a knowledge solely relevant and useful within that particular context, geographic locality and cultural cosmology (see Vitebsky 2003). Others view shamanism as a global phenomenon, with many similarities across differing societies, and argue that its wide existence is rooted in fundamental capacities and similarities in human biology and consciousness that are as relevant today as they were in the hunter-gatherer communities of the past (Winkelman 2000).

Much of the recent literature on the healing and therapeutic facets of shamanic techniques are in line with this universal understanding of shamanism across cultures and focus on the use of fasting, drumming, song, dance, theater or psychoactive plants for accessing a heightened and amplified state of awareness, or "non-ordinary state of consciousness" (Grof 1985; Noll et al. 1985). It is within such states that practitioners have been thought to access knowledge, carry out spirit travel or make necessary visits to spiritual or mythological planes of existence. In terms more fitting with modern psychotherapy, shamanic techniques are here seen as methods for accessing the subconscious and innate therapeutic potentials within the individual.

\section{The Call}

In the anthropological literature on the classic Siberian shamanism, the shamanic calling is described as an overwhelming personal encounter with an electing spirit or 
spirits that, through persuasive means, bid the individual to become a shaman and offer their help in the process. The encounter often occurs at puberty and is generally accompanied by serious illness, fainting or overwhelming visions, a juncture referred to as the shamanic illness or crisis. The individual usually refuses the calling at first, seeing it as a burden inevitably depriving him or her of a normal life, but eventually may accept the call when he or she realizes that the only other option is serious long-term illness. The successful navigation through this time can result in the initiate developing the ability to help or heal others and act as a mediator between earth and spirit planes (Madsen 1955). Similar patterns are seen in a number of cultures and have contributed to the concept of the "wounded healer" found in Jungian psychology as well as in contemporary understandings of the therapists role in therapy (Kirmayer 2003).

Although this classic Siberian model of the calling of the shaman is often outlined in the literature, there are also many variations throughout different cultures. Some may start training soon after birth; others receive the role through inheritance or later in life, after serving long years in secular functions. Sometimes the training is through a spirit guide; other times, through one or several experienced shamans (Krippner 2002).

\section{Roles}

The diverse functions of shamans spring from their role as mediator between the human group and the supernatural forces or, possibly, seen from another angle, their ability to access information through heightened states of awareness. Illness was seen either as soul-loss or as the intrusion of an object or spirit into a patients' body; diagnosis was aimed at discovering these causes, and treatments at curing them. Soul-flight was used to find and retrieve the lost soul, and (among other things) sucking or drawing movements to remove intrusions (Backman and Hultkrantz 1978). While healing was an important part of the shaman's functions, there were traditionally many others. Shamans could be used as diviners to shed light on past and future events or find lost persons and things. Another important function was that of escorting the souls of the dead to the next realm. Shamans also had important roles in hunting, either calling animals or locating them through divination (Krippner 2002).

\section{Historical Context: The Noaidi in Times of Change}

The original pre-Christian Sámi religion and spiritual life are thought to have been intimately interwoven with the lifestyle and the surrounding arctic nature (Bergman et al. 2008) - a nature that was seen as an expression of the creative energies inherent in the gods and goddesses within Sámi mythology (Myrhaug 1997). The noaidi played a central role as an intermediary between the spirit and the human planes in Sámi life (Pollan 1993). Although female Sámi shamans are known to have existed, Sámi shamans are thought to have been primarily men, often having female assistants - distinguishing the tradition from Seidr, the shamanic practices of 
the neighboring Nordic agricultural communities primarily practiced by women (Blain and Wallis 2000).

The original shamanic tradition of the area seems to closely follow that of Siberia in several ways. Drumming and a unique form of song or chant, locally called joik, were used as a means for spirit travel, contacting the forces of nature, finding animals and negotiating cures (Price 2001; Sergejeva 2000). A few Sámi shamanic drums from earlier times are still in existence, and a rich iconography on these drums has granted some understanding of traditional Sámi cosmology (Keski-Säntti et al. 2003). The cosmos was divided into three realms - the earth, the heaven and the underworld - all of which were mapped on the drums with symbols representing these different regions and their inhabitants. Included on some drums were also symbols from the culture of the neighboring Nordic peoples, including Nordic mythology and, later, Christianity - an indication of a clear confluence of tradition even from earlier times (Backman and Hultkrantz 1978; Pollan 1993). Recruitment of the noaidi was also similar to that known within classic Siberian shamanism, in which the shaman to be, often during a period of crisis and visions, was approached by helper spirits that made it clear that he or she should take on the role of a shaman (Backman and Hultkrantz 1978; Miller 2007).

A particularly severe missionary activity, initiated by the Danish king, was carried out in most Sámi areas of Norway during the sixteenth and seventeenth centuries (Berglund 2005). Drums were outlawed and burned. Some noaidi were accused of witchcraft and tried during the witch trials of the area (Hagen 2002). This suppression of Sámi tradition through the church was a central part of the political power play in the area and later continued in the form of the assimilation policies of the Norwegian government until the late 1950s. These policies targeted both culture and language. Many Sámi children were separated from their parents and sent to boarding schools where they were punished when using their mother tongue. The resulting loss of language and suppression or concealment of aspects of Sámi culture are seen in many areas today. In the coastal regions of northern Norway and more southerly Sámi regions, Sámi is now only spoken by a few of the elderly. However, in the northern inland areas of Finnmark, Sámi is still widely spoken.

Throughout the region there has, during the last decades, been a general cultural revitalization that has included attempts at reviving the language through Sámi schools and language courses, and Sámi is now, alongside Norwegian, an official language in communes with a substantial Sámi population. The cultural revival in the region has many facets, including the establishment of the Sámi parlament in the inland town of Karasjok. Another poignant symbol of it is Riddu Riddu, a popular annual international indigenous music festival held for the last 19 years in Mandal along the coast of Nord-Troms. This music festival is also a signpost of the active emergence, renewal and modernization of Sámi music tradition, which itself is closely linked to the original healing tradition of the area. Mari Boine Person, the best internationally known Sámi musician, has also openly pointed out the importance that joik (Sámi chanting tradition) has played in a healing process of her own. 


\section{Healers Today}

\section{Becoming a Healer}

We have often heard from the time we were children that there are people who can remove pain and illness, and it is because we believe in this that we seek help from them.

The view that some people, either men or women, have a gift or ability to heal or help others is widespread throughout the region and often spoken of and integral to conversations on the subject. Some of the elderly, however, told that, a generation or two ago, healers had different gifts and were specialized in different areas. Some were known to remove pains of different sorts, others to stop bleedings and still others to find lost or stolen articles. Some of these healers are still renowned in the area as particularly skilled and respected healers, and many stories circulate about the cures they have performed.

One elderly healer told that people began visiting her for healing while she was still a child. Her sister had been bothered by severe eczema, and after her mother had brought the sister to the local doctors and healers without help, she finally asked the young girl to try. The eczema soon cleared. She became known for such abilities and was thereafter visited for healing by many. This story was, however, little representative, as most healers we spoke with became active as healers later in life, often going through a period of personal difficulties in health, work or family life before openly working with healing. Some also described a transitional period during which they gradually became aware of and comfortable with their abilities, in parallel with these being gradually acknowledged by others.

All healers that we met had other healers in their family and emphasized this family heritage as an important part of their background. Usually an important ancestor, generally a parent or grandparent, had worked as a healer, and some remembered their parents or grandparents being contacted by many people during their childhood. One, however, told that although he also had family members who had been healers, he had "inherited" his abilities from an older man outside of his family whom he had met seemingly by chance. This older man had recognized him as his successor at their initial meeting. When the older man died, the younger man had a powerful personal experience of receiving the ability to understand others and a gift to heal that he had not previously possessed. He understood this as the power from the older healer being passed onto him. This passing of the healing ability as a dynamic force reflects earlier stories of the noaidi and is, also, suggested as a continuing form of inheritance in a recent anthropological thesis from the area (Miller 2007).

\section{Ways of Helping}

The stories told of healing experiences are often detailed and colorful. Here is one told a number of years after it happened by a health professional who took her daughter, while an infant with extreme colic pains, to a helper, living miles from her home, one very cold winter night. The materialization of small, dark, beard-like 
hairs on the child's back during the cure is unique in this material, and especially striking as, although the story was actually told by a health professional, any physical medical explanation is hard to find. Although somewhat long, much of the story is included here to give a feeling for the detail and color that are a part of nearly all the stories of healing we heard.

When my oldest daughter was little, she screamed all the time. Night and day. She didn't sleep. We thought it was baby colic. That's the first you think aboutbut it was strange, she bent backwards in an arch during the pains. When we tried stroking her back, she got even worse, and just tossed her head about and screamed more. So we tried everything - me not drinking milk, or eating this or that. But nothing helped! We started to think it might be an autistic trait, so she was sent to the hospital for three days of observation. They observed the child, but couldn't say what it was. They said it must be colic even though she didn't act like a "colic baby," and they described the same thing.

The narrator continues to tell that one day a woman from Kvikkjokk, a Swedish Sámi village several hundred kilometers away, came to work where her husband was working.

She saw that my husband was completely beat (from being awake all night), and one of his co-workers told the story of our daughter. The woman said, "Maybe she has sticker $i$ ryggen" [splints or sticks in the back]. "Sticker $i$ ryggen. What is that?" "Haven't you heard of that, that's completely normal, some kids have sticker $i$ ryggen." And when she described how these kids with it act, my husband understood that this fit for our daughter. The woman told that her mother could remove them, and that many kids come to get them removed. So we called her mother. It was winter and cold, and she said she lived far off, so we should try ourselves to massage her back with some oil, and the stikker would come out. So we tried, and she just started screaming even more, so we gave up.

A few months later my husband was going to Jokkmokk [a town close to where the elderly healer was living]. So I called the old woman and said, "My husband is going to drive there. Can I come?" I remember it was 36 below zero. "But it is so cold," she said. "Can I just come?" [narrator persisting]. She said, "Just come." So I went with him and drove to Kvikkjokk. So we were sitting in her living room. She had an open fireplace. She took off the child's clothes, so she was completely naked, and started (to massage the child's back). And out started to come-and I can't explain it in any other way than it was like petrified hairs, like beard growth in men, that came out of her back. Her whole back was full. On both sides, she didn't have any in the middle bony part, but on both sides and over her whole shoulder area and up her neck. This was an old woman, and she had a magnifying glass. She said to me, "You who can see well, can't you pluck them out?" So she continued stroking her back, and I plucked them out and put them in my hand. Most of them, around 90\%, were at most one centimeter, but some were very long and curled at one end. Then she said that you could see that she had had them for a long time, as some had already started to curl up. She said that these 
live under the skin, and when you stroke the back, you get them to live - and then they lie under and press - and that's why it hurts and the child screams. While we were doing this, the child really screamed! When she said that we were finished, my hand was full, and I went over to the fireplace and threw them in the fire without thinking. When I got home, I put the child to bed, and she slept until eight in the morning. When I awoke and realized that it was eight and I hadn't heard anything, I thought she was dead. I rushed over and shook her. She was just sleeping. She had slept through the entire night. After that she slept.

Many years later, one woman I had told the story to had told it to her mother, who knew a little bit of everything, to put it in that way [referring to someone with more than common knowledge]. Everyone asked me why I didn't save the hairs as evidence, and I regretted burning them. Anyhow, this old woman said, "You must ask what she did with the sticker." She said they had to be burned or they would go over to another person. So-I had automatically gone over to the fireplace and burnt them.

The doctor we went to didn't understand why she had suddenly gotten well. So I told him the story. Then he had a good laugh and said, "Aha, so you believe in the old wise woman." I said, "I don't care what she did, what matters to me is that my daughter is finally well, and that is more than you could manage I am satisfied." But nine months later, he called me because he had a new child - with the same symptoms - and he wanted the old woman's telephone number. So he was wise enough to actually do that. Both our daughters have heard this story many times....

The healers we spoke with did not call themselves healers and stressed that they were only a tool or a channel for some force outside of themselves. Sometimes the force was referred to as God; sometimes it was not specified. Locally these people are often referred to as helpers and work mostly in their own homes, often free of charge, as has been the tradition. Although there are many ways a helper can work - through conversation, the laying-on of hands or the use of plants - they are commonly contacted by phone and help or heal over a distance. Lasing, literally meaning reading in Norwegian, is the use of special verses passed on from generation to generation and known only to the healers. These verses are thought to come mostly from biblical tradition and are often used when treating from a distance. In some cases a healer is called when the patient is in the hospital. In the words of a patient who had called a healer for help before a major operation, "It was the healer who prayed that the doctors would receive wisdom from God so they could carry out this operation they had never done before."

When healing is done through the laying-on of hands, it is often explained as a way of "pulling out" pain and illness, and healers may often feel the pain itself, or the nature of the pain, when touching patients and shake the absorbed pain away from their own hands or wash them in flowing water after a session. One healer pointed out that releasing any negative accumulations that may have been absorbed was important for healers and that this should be given more awareness among health professionals working in clinic settings. 
Some of the healing work takes on more of a ritual form. An example in laesing is saying the verses to water and then giving the water to a patient, sometimes to be taken over a period of time. One healer told how she would similarly laese to fire in cases of burns or to other natural elements from which the illness was thought to arise. If a rash was seen to come from a swamp, moss from the swamp was first read to and then passed over the body of the person with the rash. If the rash came from a river or stream area, the patient and healer may go to the stream and carry out the reading. Similarly, many healers carry out cleansing of homes and places where people have heard and experienced noises or unexplainable things thought to be spirits of the deceased. In such cases matches or candles may also be used throughout the house to bring "light" to the house and help the attached spirits move out and into the light.

More natural medical techniques are also used, although these are mostly referred to in stories of healings in the past, and elders believe these traditions have disappeared to a great degree. Such techniques, told of in a number of the narratives, include the use of earth or turf from specific areas for skin problems and the knowledge of specific herbs and plants for inner or outer ailments. Cupping, or a form of suction treatment, where a vacuum is formed within a cup and placed on the surface of the body, as well as a the burning of an herb over points on the body, both similar to treatments known from Chinese medicine, were common earlier, yet are only scarcely in use today.

\section{Sources of Knowledge}

Although helpers had often grown up close to a family member who was a healer, the kind of knowledge they emphasized was not one of learning. Helpers rather explained in one way or another that they received knowledge from somewhere inside themselves or from some source they could not explain. One, when asked how he did his healing, responded, "It is inside me, I do as I believe I am supposed to." One who was often contacted by phone for help told how the first thought that came to her when someone called was essential and often suggested what the problem was:

It is like someone (inside me) tells me things, that things are this way or that ... that this person has a particular illness.... It comes from above.... And if I ignore the thought, and don't do it, they don't get well. I have tried to get used to it, the first thought that comes, and not overlook it.

She also told that although she knew special verses used in lasing, sometimes other words would come to her as an inner voice or thought. Another helper explained it as if her awareness was raised to another level beyond herself in which she would receive insights that could be useful for those who came for help. She could also experience this at times in her own personal life and felt that she received valuable practical direction that she could use in her everyday life.

One helper, who had come from a long line of healers, had had a series of out-ofbody experiences as a young child in which she experienced traveling beyond her home and seeing things throughout the neighborhood, things she could later confirm 
actually happened. When she spoke to her parents about this, she was adamantly told not to speak about it and, so, kept the experiences inside her until adulthood, not daring to tell anyone and feeling ashamed of the experience. As an adult, she was contacted when people needed help finding lost or stolen objects and explained that she would often, in a similar way as during childhood, receive a picture or vision of where something was or how it had happened that an item had been lost or stolen.

Both helpers and others we spoke with in the area told of many experiences of precognition, of knowing things before they happened, especially unexpected deaths or tragedies. This could come in a dream or was described as a bodily knowing, sometimes a sense of unease:

You know, when it comes to death, I feel so strange in my stomach when I look out the window, and I can't sit still, and I tell others that now I know for sure that I will hear someone has died.... It has been like this for me for years.

Another reported:

I have in some way known before something is going to happen that it will. But it has been-many times it has been very tiresome. My grandmother was the same way, so my mother said that I had probably inherited this from her.

One healer told of how she used to work herding with her grandfather, a renowned healer, in the mountains several hours from the village, at a time before there were telephones and doctors in the area. Sometimes while they were working he would suddenly say that they had to return to the village as So-and-So was sick, naming the individual. Upon returning they would find the person in question in need of help.

\section{Framing in Different Traditions}

Broadly, each of the rural Sámi healers here leaned toward what might be thought of as either more of an indigenous or more of a Christian tradition. In addition, a few of the somewhat younger healers in the area held perspectives that were more global or composite, including obvious influences from sources such as the Indian Chakra system or Native American medicine or even modern knowledge of vitamins and minerals. Although these perspectives might be thought to be more complementary, they were held by people who were in a family line of healers and, also, practiced healing as had been done by their parents or grandparents.

Within a more indigenous tradition, personal access to a healing force and an intuitive knowledge were central. Several of the healers stressed that the tradition was similar to what had been practiced for thousands of years and had parallels to that practiced in other indigenous communities. Although witchcraft, locally called ganning, is believed by some to be the cause of illness, often mental illness, healers we spoke with did not emphasize to us that witchcraft was an important source of illness today. However, several mentioned that the forces used in healing could be used toward both positive and negative ends, and in some of the stories of healing a particular healer was sought out to dispel a curse. 
Although others clearly framed their work within a Christian tradition, such as those who used laesing, and had a personal affiliation with the Læstadian Christian movement, they still held many of the same understandings found within the traditional or indigenous tradition. They would, for example, tell stories that referred to encounters with spirits, or beings in nature, and used natural medical techniques, yet explained these within a Christian framework, as illustrated in the initial story.

\section{Shamans Today}

Two of the healers we spoke with called themselves shamans and had started to use shamanic drums in their practice. Although coming from the region and from families with traditional healers and readers, they differ from the other rural healers-who did not call themselves shamans or use drums. However, they view their practice as the continuance of a tradition that goes back to the pre-Christian noaidi. The shamanic drum is important in the work of both, and through it they experience contact with ancestors, other spirit beings or animal spirits from whom they may receive inspiration, power or some form of knowledge. Although grown up in the rural culture of healing, they are both active instruments in transforming it. Both hold courses and have internet pages describing their services.

One tells that there have been many Sámi noaidi in his family back to the $1500 \mathrm{~s}$ and that both his father and grandmother, who was especially skillful with animals, were sought out for help. In the 1970s he received reading verses for stopping bleeding, inflammations and eczema from his father, who wished him to continue the heritage. He slowly began using these verses at times-stressing that they could actually be used for many conditions. Coming from a coastal area with a strong history of Norwegianization, his first identity during this period was as a Norwegian. In the late 1970s he became active with the Alta Dam demonstrations (when young Sámi activists protested against the damming of the Alta-Kautokeino watershed), and this increased his Sámi identity. He took several courses from healers, on both chakras and shamanism. Slowly people began to refer to him as a noaidi. Although originally skeptical of the modern revival of the drum, he eventually also took one course with Ailo Gaup, who was one of the first Sámi to once again use drumming in Norway. During this course he felt that he came in contact with the "force within shamanism," which gradually grew in him. During the early nineties he gradually began to practice more healing, both distant and present. Although inspired also by other sources outside of Sámi tradition, he feels that his practice is primarily Sámi. He also feels flexible in changing some aspects of tradition, such as in incorporating new reading formulas that come to him. He has stopped using some of the old formulas, although he still feels that the Lord's Prayer is particularly important and imbued with a special power, having been used for so many generations. He uses a variety of techniques, including the laying-on of hands, prayer, affirmations, voice, movement and body therapy, and as drum journeying for individuals and groups. He points out the importance of surprising patients with unexpected questions, and that this element of surprise is a part of the Sámi culture and language. He explains that it was a technique also used by Jesus to help get 
people out of stuck thought patterns. He speaks of how a force is transmitted through the hands, and that this transmission of a force was also central to Sámi healing when steel (often the blade of a knife) was used earlier in healing. He tells how he believes that the old traditions were carried on through laesing when the drum was forbidden, and has a modern understanding of the healing force as energetic frequencies that are conducive to healing. He stresses the importance of working with the particular belief system of the client, emphasizing how today it varies considerably from person to person. He also experiences that there is some form of unidentifiable connection that occurs among the different therapies clients use. As their lives transform, so does the input of the different therapies and therapists. Sometimes after a client has been to him, the client's doctor, who might for a long time have been struggling with the client's condition, will get a new insight about it.

\section{Discussion: The Noaidi and Healers of Today}

Leaving aside the re-emergence of shamanism for the moment, a major and clear difference between the tradition of the rural healers and that of the original noaidi is the fact that the drum as a central instrument of the healing disappeared generations ago. With the loss of the drum was also the loss of a key symbol of the healing tradition, as well as a vital tool for inducing states of awareness conducive to healing. However, healers today do tell of experiences of expanded states of awareness, receiving knowledge from somewhere inside themselves and encountering spirit beings—all themes linked with the earlier tradition of the noaidi. Some of the literature on Sámi shamanism also suggests that noaidi may have been less dependent on the use of the drum for their visionary and divinatory practices than often thought (Miller 2007). The critical role of the drum has also been questioned in research among some Siberian tribes where those considered to be especially powerful shamans were found to be relatively independent of its use (Barkalaja 2004). These observations have led some to propose that shamanism should be considered more a system of beliefs than a technique of ecstasy (Barkalaja 2004), in which case, the question of links between the rural healing tradition and that of the noaidi should focus more on beliefs, related personal experiences and understandings of reality rather than on outer techniques. In other words, we should not necessarily equate the loss of the drum with the loss of the healing tradition that it was a part of.

The initial account of the elderly healer speaks of the potential for helpers from another plane to appear and help in times of need, a theme also found in other stories we heard and clearly mirroring the shamanic tradition of the past. Another theme in her narrative, which also possibly echoes past tradition and beliefs, is the theme of the boat, or ferry. In her dream she interpreted the ferry as a shuttle to the next life. Boats are known to have often been depicted both on the drums of the noaidi from the seventeenth century and on Sámi petroglyphs as far back as 4000 $\mathrm{BC}$, and boats are believed to have symbolic meaning as vehicles connecting the plane of the living and the spirit plane of the dead (Bayliss-Smith and Mulk 1999)_ a meaning the healer similarly interpreted within her own dream, and that is actually 
found in other shamanic traditions. Although a direct connection between her own dream interpretation and the ancient symbolism of the boat is hard to make, a possible echo is clear.

The role Sámi rural healers play as readers and healers is in many ways reminiscent of the shamanic role of mediator between realities. This may be seen in their initial personal ordeals before they began actively working with healing, in their possession of extraordinary gifts and abilities, in their "initiation" into special knowledge (e.g., the verses used in reading) and in their capacity to serve as a channel for a force outside themselves. The understanding of healing as a force that can act over a distance, be transmitted between people or between a healer and his or her chosen successor, also resonates with a shamanic worldview in which reality is seen as a spirited continuum of connections. This continuum of connections-or animated Universe-is also seen in reading to water and fire or in cleansing a home with candlelight.

If these similarities do represent a continuance of tradition, one might ask why certain aspects of the shamanic culture, such as the drum, have (until the present revitalization) been completely lost, while other aspects, such as the belief system, have persisted. The extreme suppression of the drum may have had much to do with both its concrete symbolic representation of shamanic tradition and the fact that it traditionally provided a direct source of contact with the divine that was particularly threatening to representatives of the church. The suppression of the drum as "a tool of knowledge" may have resulted in some form of its function being integrated within the society or individuals in new ways. This may help to explain the large number of accounts we heard of other forms of knowing, precognition and similar experiences among participants. Such an integration, or internalization, of the function of the drum may have been especially relevant in certain family lines. When the outer tools of healing as well as the cultural fabric for preserving tradition were weakened and lost, some families could keep the tradition more intact through social and genetic inheritance. Such an association is supported by literature describing the close link between shamanic practices and our neurobiological makeup (Winkelman 2000), as well as in studies showing that the ability to access trance states is both inherited (McClenon 1997) and developed through social processes (Nelson 1975).

The fact that many of the stories told in this region are interspersed with experiences found within shamanic tradition reflects a persistent and strong narrative tradition that helps to explain why worldviews and belief systems have endured. Jens Ivar Nergård, who has done extensive fieldwork in northern Sámi areas of Norway, has pointed out the central importance of such narratives in preserving Sámi culture and providing a blueprint for both experiencing and understanding reality among people today (Nergård 2006).

An additional point in the continuance and transformation of Sámi tradition is the Læstadian church, which was established by a man of Sámi background in the mid eighteen hundreds and is known to have incorporated ecstatic group worship with parallels to healing ceremonies of the past (Miller 2007; Nergård 2006). This form of Christianity seems to have been used as a legitimizing vessel for local traditions as suggested by several participants in this study. A similar continuation of 
traditional beliefs and ritual elements within church settings has also been described in a number of arctic regions such as Greenland, Finland, Alaska and Siberia (Dutton 2007; Kan 1991; Pentikainen 1998), as well as in other cultural and geographical settings where Christianity has met indigenous traditions (De Alverga and Polari 1999).

Although some of the worldviews inherent within local tradition seem to persist, it is also clear that knowledge is quickly being lost. According to the elders in Sámi areas, certain healing techniques such as cupping and the use of herbs are in use far less, or not at all, today. In contrast, there is an ongoing process of renewal of tradition.

The last two healers we spoke to in this study represent a new wave of tradition that is both connected to and distinct from that of the rural healers. Their revival of the use of the shamanic drum is, needless to say, a very significant turn in the transformation of tradition today, and one that awakens diverse reactions in local communities, as well as academics interested in healing traditions. Some locals consider the word shaman or noaidi to be negative; others believe that there are strong economic interests driving modern shamans. Whether these modern-day shamans actually do fulfill an academic definition of a shaman will also always be the subject of debate. It is clear that their role today is more toward the individual than the group and that their worldviews are a composite influenced by many global traditions. Although the potential for reviving traditions that were originally embedded in an entirely different cultural framework is often questioned, the modern-day shamans appear to have arisen out of a cultural framework with links to the past. For those studying culture, these links are carried on through diverse aspects of Sámi life, a strong narrative tradition and a vital yet transforming healing tradition. For the modern-day shamans themselves, such links are in their family ties to the noaidi and in their inner-spirit communication and connection with healers, shamans and ancestors of the past.

There seem to be clear ties between the Sámi shamans of earlier times and the rural healers and modern shamans of today, of several kinds. Considering that the realities accessed by the shamans of the past may, in addition to being informed by culture, in fact be potentials innate in human nature, helps to explain the persistence of tradition through long periods of suppression. It also suggests that the past and today may be at least as close as, or even closer than, their outer similarities might portray.

Acknowledgments This study has been a communal effort to which a number of people contributed. First, we would like to thank those healers and clients who have shared their experiences and knowledge. We would also like to thank Tore Sørlie for his guidance in developing this article, as well as Jens-Ivar Nergård, for his perspectives on the narrative tradition. Many thanks also go to Marit Einejord, who transcribed the Sámi interviews in Sámi and translated them into Norwegian. This translation was, needless to say, quite a major work. We would also like to thank those who have written earlier work on these traditions, an important source of information and knowledge that has provided a vital foundation for our work. A special thanks goes to Amy Sexton for her important and constructive comments on the manuscript. Finally, we would like to thank Helse-Nord, the Sámi Parliament and the Sámi National Center for Mental Health for their financial support.

Open Access This article is distributed under the terms of the Creative Commons Attribution Noncommercial License which permits any noncommercial use, distribution, and reproduction in any medium, provided the original author(s) and source are credited. 


\section{References}

Backman, Louise, and Åke Hultkrantz

1978 Studies in Lapp Shamanism. Stockholm: Gotenborgs Offsettryckeri AB.

Barkalaja, Anzori

2004 Shamanism as Information Design. In Shamanism in the Interdisciplinary Context. Art Leete and R. Paul Firnhaber, eds., pp. 21-55. Boca Raton, FL: BrownWalker Press.

Bayliss-Smith, Tim, and Inga-Maria Mulk

1999 Sailing Boats in Padjelanta: Sámi Rock Engravings from the Mountains in Laponia, Northern Sweden. Acta Borealia 16(1): 3-41.

Berglund, Birgitta

2005 Recently Discovered Gievrie (South-Saami Shaman Drums). Acta Borealia 22(2): 128-152.

Bergman, Ingela, Lars Ostlund, Ole Zackrisson, and Lars Liedgren

2008 Varro Muorra: The Landscape Significance of Sámi Sacred Wooden Objects and Sacrificial Altars. Ethnohistory 55(1): 1-28.

Blain, Jenny, and Robert J. Wallis

2000 The Ergi Seidman: Contestations of Gender, Shamanism and Sexuality in Northern Religion Past and Present. Journal of Contemporary Religion 15(3): 395-411.

De Alverga, Alex Polari

1999 Forest of Visions: Ayahuasca, Amazonian Spirituality, and the Santo Daime Tradition. Rochester, VT: Park Street Press.

Dow, James

1986 The Shaman's Touch: Otomì Indian Symbolic Healing. Salt Lake City: University of Utah.

Dutton, Edward

2007 A Shared Pre-Christian Past? Contemporary Finnish Baptism in Light of Greenlandic Naming Rituals. Internet Journal of the Anthropology of Religion. Available at: http://www.anpere.net/ 2007/13.pdf. Accessed June 30, 2010.

Gergen, Kenneth J.

1999 An Invitation to Social Construction. London: Sage.

Grof, Stanislav

1985 Beyond the Brain: Birth, Death, and Transcendence in Psychotherapy. Albany: State University of New York Press.

Haetta, Ole Mattis

1993 The Sámi. An Indigenous People of the Arctic Karasjok: Davvi Girji.

Hagen, Rune

2002 Harmløs dissenter eller djevelsk trollmann? Trolldomsprosessen mot samen Anders Poulsen i 1692 [Harmless Rebel or Devilish Sourcerer? The Witchtrials Against the Sámi man Anders Poulsen in 1692]. Historisk Tidsskrift 81: 319-346.

Ingman, Max, and Ulf Gyllensten

2007 A Recent Genetic Link between Sámi and the Volga-Ural Region of Russia. European Journal of Human Genetics 15: 115-120.

Kan, Sergei

1991 Shamanism and Christianity: Modern-Day Tlingit Elders Look at the Past. Ethnohistory 38(4): 363-387.

Keski-Säntti, Jouko, Ulla Lehtonen, Pauli Sivonen, and Ville Vuolanto

2003 The Drum as Map: Western Knowledge Systems and Northern Indigenous Map Making. Imago Mundi 55(1): 120-125.

Kirmayer, L. J.

2003 Asklepian Dreams: The Ethos of the Wounded-Healer in the Clinical Encounter. Transcultural Psychiatry 40(2): 248.

Kirmayer, Laurence J., GregoryM. Brass, and Caroline L. Tait

2000 The Mental Health of Aboriginal Peoples: Transformations of Identity and Community. Canadian Journal of Psychiatry 45(7): 607-616.

Krippner, S. C

2002 Conflicting Perspectives on Shamans and Shamanism: Points and Counterpoints. American Psychologist 57(11): 962-977. 
Madsen, W.

1955 Shamanism in Mexico. Southwestern Journal of Anthropology 11: 48-57.

McClenon, James

1997 Shamanic Healing, Human Evolution, and the Origin of Religion. Journal for the Scientific Study of Religion 36(3): 345-354.

Miller, Barbara H.

2007 Connecting and Correcting. A Case Study of Sámi Healers in Porsanger. Ph.D. thesis. University of Leiden.

Myrhaug, Marit L.

1997 I modergudinnens fotspor. Sámisk religion med vekt på kvinnelige kultutøvere og gudinnekult [Sámi Religion with Emphasis on Female Cult Practitioners and Godess-cult] Oslo: Pax Forlag A/S.

Nelson, Geoffrey K.

1975 Towards a Sociology of the Psychic. Review of Religious Research 16(3): 166-173.

Nergård, Jens-Ivar

2006 Den Levende Erfaring, en studie i Sámisk kunnskaps tradisjon [The Living Tradition, a Study in Sámi Knowledge Tradition]. Oslo: Cappelen.

Noll, Richard, Jeanne Achterberg, Erika Bourguignon, Leonard George, Michael Harner, Lauri Honko,

Åke Hultkrantz, Stanley Krippner, Christie W. Kiefer, and Richard J. Preston

1985 Mental Imagery Cultivation as a Cultural Phenomenon: The Role of Visions in Shamanism. Current Anthropology 26(4): 443-461.

NOU

1994 Norges Offentlig Utredning. Bruk av land og vann i Finnmark i historisk perspektiv [Norwegian Governmental Document. Use of Land and Water in Finnmark in a Historic Perspective]. No. 21. 443 pp. Oslo: Statens forvaltnngstjeneste, seksjon statens trykking.

Pentikainen, J.

1998 Shamanism and Culture. Tempere, Finland: Etnika.

Pollan, Brita

1993 Sámiske sjamaner: religion og helbredelse [Sámi Shamans: Religion and Healing]. Oslo: Gyldendal.

Price, Neil S.

2001 An Archaeology of Altered States: Shamanism and Material Culture Studies. London: Routledge.

Sergejeva, Jelena

2000 The Eastern Sámi: A Short Account of Their History and Identity. Acta Borealia 17(2): 5-37.

Sexton, Randall, and Tore Sørlie

2009 Should Traditional Healing Be Integrated Within the Mental Health Services in Sámi Areas of Northern Norway? Patient Views and Related Factors. International Journal of Circumpolar Health 68(5): 488-497.

Sørlie, Tore, and Jens-Ivar Nergård

2005 Treatment Satisfaction and Recovery in Saami and Norwegian Patients Following Psychiatric Hospital Treatment: A Comparative Study. Transcultural Psychiatry 42(2): 295-316.

Vitebsky, Pierce, ed.

2001 Shamanism and the Rigged Marketplace. London: Thames \& Hudson Ltd..

2003 From Cosmology to Environmentalism: Shamanism as Local Knowledge in a Global Setting. London: Routledge.

Winkelman, Michael

2000 Shamanism: The Neural Ecology of Consciousness and Healing. Westport, CT: Greenwood Press.

World Health Organization

2002 WHO: Traditional Medicine Strategy 2002-2005. Available at: http://www.who.int/medicines/ publications/traditional/policy/en/. Accessed December 19, 2008. 